\title{
Effects of Rock Mass Conditions and Blasting Standard on Fragmentation Size at Limestone Quarries
}

\author{
Takashi Sasaoka1 ${ }^{*}$, Yoshiaki Takahashi' ${ }^{1}$, Wahyudi Sugeng ${ }^{1}$, Akihiro Hamanaka ${ }^{2}$, \\ Hideki Shimada', Kikuo Matsui ${ }^{1}$, Shiro Kubota ${ }^{3}$ \\ ${ }^{1}$ Department of Earth Resources Engineering, Faculty of Engineering, Kyushu University, Fukuoka, Japan \\ ${ }^{2}$ Center of Environmental Science and Disaster Mitigation for Advanced Research, Muroran Institute \\ Technology, Muroran, Japan \\ ${ }^{3}$ National Institute of Advanced Industrial Science and Technology, Ibaraki, Japan \\ Email: ${ }^{*}$ sasaoka@mine.kyushu-u.ac.jp
}

Received 16 April 2015; accepted 15 May 2015; published 18 May 2015

Copyright (C) 2015 by authors and Scientific Research Publishing Inc.

This work is licensed under the Creative Commons Attribution International License (CC BY).

http://creativecommons.org/licenses/by/4.0/

(c) (i) Open Access

\section{Abstract}

The size distribution of fragmented rocks depends on not only the blasting standard but also the mechanical properties, joint system and crack density of rock mass. As, especially, the cracks in the rock mass are heavily developed at the limestone quarries in Japan, the joints and/or cracks in the rock mass have big impacts on the blasting effects such as the size of fragmented rocks. Therefore, if the joint system and/or crack density in the rock mass can be known and evaluated in quantity, the blasting operation can be done more effectively, efficiency and safety. However, the guideline for designing the appropriate blasting standard based on the rock mass condition such as mechanical properties, joint system and/or distribution of cracks, discontinuities, from the scientific point of view, has not been developed yet. Therefore, a series of blasting tests had been conducted in different mines and faces, geological conditions and blasting standards in order to know the impacts of each factor on the blasting effects. This paper summarizes the results of blasting tests and describes the impacts of rock mass conditions and blasting standard on the size of fragmented rocks.

\section{Keywords}

Fragmentation, Borehole Camera, Mechanical Properties of Rock Mass, Crack Density, Blasting Standard

\footnotetext{
${ }^{*}$ Corresponding author.
}

How to cite this paper: Sasaoka, T., Takahashi, Y., Sugeng, W., Hamanaka, A., Shimada, H., Matsui, K. and Kubota, S. (2015) Effects of Rock Mass Conditions and Blasting Standard on Fragmentation Size at Limestone Quarries. Open Journal of Geology, 5, 331-339. http://dx.doi.org/10.4236/ojg.2015.55030 


\section{Introduction}

Rock blasting is the rock excavation technique most widely adopted in the various fields of the mining and construction industries because of its economical and efficient aspects [1].

In surface mines and quarries, the main objective is to exact the largest possible quantity at minimum cost. The material may include ore, coal, aggregates for construction and also the waste rock required to remove the above useful material. The blasting operations must be carried out to provide quantity and quality requirements of production in such a way that overall profits of mining or quarrying operation are maximized. In-situ rock is reduced in size by blasting and crushing into the required size or with additional grinding, into a fine powder suitable for mineral processing. Large blocks needing secondary breakage or an excess of fines can result from poorly designed blasts or due to adverse geological conditions. A well designed blast should produce shapes and sizes that can be accommodated by the available loading and hauling equipment and crushing plant with little or no need for secondary breakage [2], while optimizing the fragmentation is also important for safety and ease of loading.

Blasting designs in mines are still optimized over months or years by trial and error [3]. Hence, a series of blasting tests were conducted in different mines, locations, and rock mass conditions by using a borehole camera and software for fragmentation analysis. Then, the effects of rock mass conditions such as fracture, discontinuity, mechanical properties of rocks and the blasting standard on the size of fragmented rocks were discussed in order to develop the guidelines for designing optimal blasting standard based on the rock mass condition.

\section{Field Experiment}

\subsection{Overview of Field Experiments}

In order to know the effects of rock mass conditions and blasting standard on the blasting effects, a series of field experiments were conducted in four different limestone quarries in Japan. Mines A, B, C are located at the northern part of Kyushu Island, Japan. Mine D is located at the southern part of Kyushu Island, Japan.In the testing sites, clay strata, joint systems/many cracks were observed in the faces at Mine A, Mine B and Mine C. On the other hand, quite a few clay strata was observed at Mine D. Table 1 shows the general blasting standards of each mine.

Figure 1 shows the procedures of field tests. At first, the blast holes and observation holes drilled in vertical and parallel to the face were observed by using borehole camera in order to know the rock mass condition especially joint system and cracks. Then, after blasting, the photograph of fragmented rocks was taken for the rock fragmentation analysis. Finally, the observation holes were observed again in order to compare the rock mass conditions before and after blasting. Besides, the rock samples were obtained at every face after blasting. Table 2 shows the results of rock property tests.

\subsection{Borehole Camera}

Figure 2 shows the borehole camera system we have developed and used so far [3]. This system consists of probe, control unit and digital video. The diameter and the length of the probe are $80 \mathrm{~mm}$ and $1.0 \mathrm{~m}$, respectively. The motorized mirror, for the single micro camera, allows one to view to the side 360 degrees of the wall of

\begin{tabular}{|c|c|c|c|c|c|c|c|c|}
\hline & $\begin{array}{c}\text { Mine A } \\
\text { Face } 1\end{array}$ & $\begin{array}{c}\text { Mine A } \\
\text { Face } 2\end{array}$ & $\begin{array}{c}\text { Mine A } \\
\text { Face } 3\end{array}$ & $\begin{array}{c}\text { Mine A } \\
\text { Face } 4\end{array}$ & $\begin{array}{l}\text { Mine B } \\
\text { Face } 1\end{array}$ & $\begin{array}{c}\text { Mine B } \\
\text { Face } 2\end{array}$ & $\begin{array}{c}\text { Mine C } \\
\text { Face } 3\end{array}$ & $\begin{array}{c}\text { Mine D } \\
\text { Face 1-3 }\end{array}$ \\
\hline Bench height (m) & 10 & 15 & 13 & 15 & 15 & 15 & 10 & 10 \\
\hline Bench angle (deg.) & 70 & 70 & 70 & 70 & 70 & 70 & 70 & 70 \\
\hline Hole spacing (m) & 4.0 & 3.8 & 4.0 & 4.0 & 5.5 & 6.0 & 5.0 & 2.0 \\
\hline Burden (m) & 4.1 & 3.6 & 4.2 & 4.0 & 6.0 & 6.0 & 5.0 & 2.5 \\
\hline Hole diameter (mm) & 110 & 90 & 110 & 90 & 140 & 140 & 130 & 75 \\
\hline Powder factor (g/t) & 91.7 & 77.5 & 92.2 & 52.8 & 112 & 102 & 66.7 & 158 \\
\hline
\end{tabular}




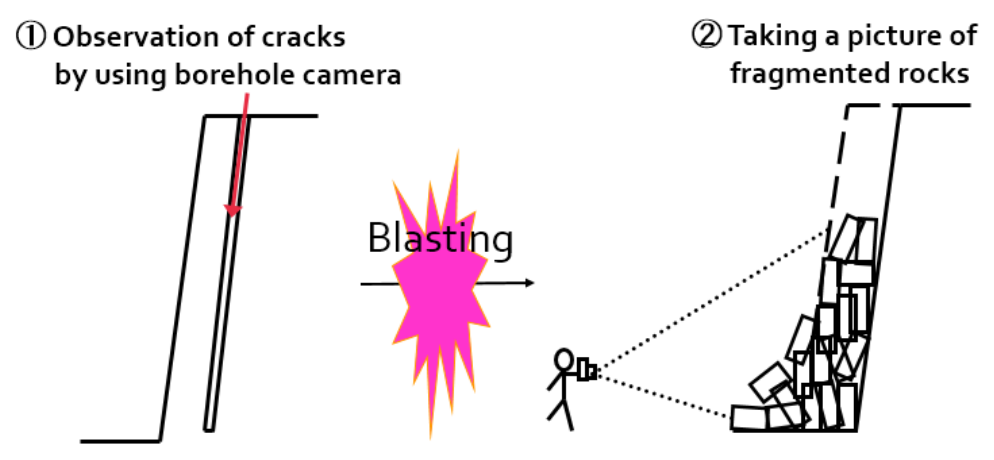

Figure 1. Illustration of test procedures.

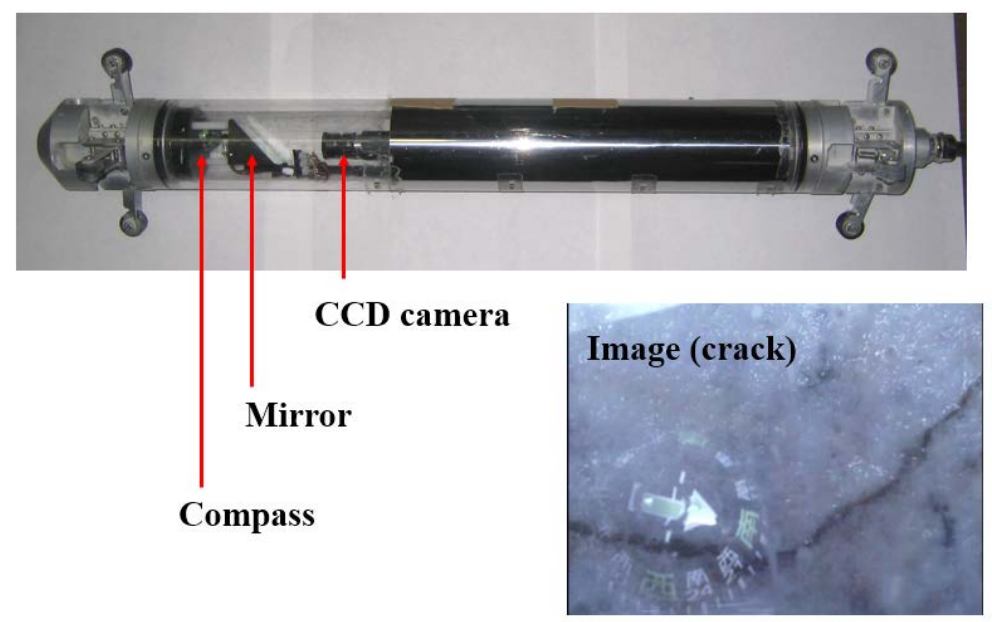

Figure 2. Borehole camera system and image.

Table 2. Mechanical properties of rocks in each mine.

\begin{tabular}{ccccccccccc}
\hline & $\begin{array}{c}\text { Mine A } \\
\text { Face 1 }\end{array}$ & $\begin{array}{c}\text { Mine A } \\
\text { Face 2 }\end{array}$ & $\begin{array}{c}\text { Mine A } \\
\text { Face 3 }\end{array}$ & $\begin{array}{c}\text { Mine A } \\
\text { Face 4 }\end{array}$ & $\begin{array}{c}\text { Mine B } \\
\text { Face 1 }\end{array}$ & $\begin{array}{c}\text { Mine B } \\
\text { Face 2 }\end{array}$ & $\begin{array}{c}\text { Mine C } \\
\text { Face 1 }\end{array}$ & $\begin{array}{c}\text { Mine D } \\
\text { Face 1 }\end{array}$ & $\begin{array}{c}\text { Mine D } \\
\text { Face 2 }\end{array}$ & $\begin{array}{c}\text { Mine D } \\
\text { Face 3 }\end{array}$ \\
\hline $\begin{array}{c}\text { Dencity } \\
\left(\mathrm{g} / \mathrm{cm}^{3}\right)\end{array}$ & 2.69 & 2.70 & 2.69 & 2.69 & 2.72 & 2.68 & 2.65 & 2.46 & 2.51 & 2.60 \\
$\begin{array}{c}\text { Uniaxial } \\
\text { compressive } \\
\text { strength } \\
\text { (MPa) }\end{array}$ & 94.1 & 91.6 & 72.8 & 108 & 57.0 & 44.4 & 65.4 & 107 & 117 & 134 \\
$\begin{array}{c}\text { Brazilian } \\
\text { tensile } \\
\text { strength } \\
\text { (MPa) }\end{array}$ & 6.58 & 7.41 & 3.36 & 6.64 & 3.00 & 5.90 & 6.28 & 7.10 & 6.34 & 11.3 \\
$\begin{array}{c}\text { RIHN } \\
(-)\end{array}$ & 37.6 & 39.0 & 5.4 & 38.8 & 3.8 & 3.9 & 56.8 & 41.7 & 36.8 & 62.5 \\
\hline
\end{tabular}

borehole. The image comes from the probe is displayed on the screen of video camera and recorded on digital video tape. The features of this system are cheap, simple and easy to carry and use it. Figure 2 also shows the image of crack and describes how to calculate the strike and dip of joints/discontinuities based on the image of borehole camera.

\subsection{Fragmentation Analysis}

Fragmentation assessment was achieved by the analysis of scaled photograph taken from the fragmented rocks. Paley recommended a procedure for taking photographs of fragmented rocks so as to minimize errors due to 
distortion [4]. Two balls with diameter of $24 \mathrm{~cm}$ were used to provide scale in the photograph. The balls were placed in the same vertical line down the fragmented rocks, preferably with one ball near the top of the fragmented rocks and the other near the bottom. The balls should not be placed randomly in the fragmented rocks nor in a horizontal line across them. The camera was held such that the long axis of the photograph is vertical. The photograph was then taken with the camera as perpendicular to the surface of fragmented rocks as possible. By having two balls on the surface of fragmented rocks, allowance was made for variable scale within the photograph when the camera could not be positioned perpendicular to the surface of fragmented rocks.

The scaled fragmentation photographs were manually digitized from the original photograph on computer screen by software known as Split-Desktop developed by Split Engineering as illustrated in Figure 3 [5]. The outlines of visible rocks above a certain minimum resolution, $3 \mathrm{~mm}$ in diameter on the photograph, were traced by mouse. After the digital image is analyzed, the particle size distribution of fragmented rock was derived as shown in Figure 4. The representative particle size at $50 \%$ of the gain size accumulation curve; $\mathrm{Xp}_{50}$ was used in this research. Table 3 shows the representative particle size at $50 \%$ of the gain size accumulation curve at each face.

\subsection{Results and Discussions}

Figure 5 shows the relationship between $\mathrm{Xp}_{50}$ and average crack space. Here, an average crack space is an average space of nearby cracks and the crack density is a number of the crack per $1 \mathrm{~m}$ along the borehole. From this figure, they have a good correlation and it can be said that crack space and/or crack frequency has an obvious impact on the size of fragmented rock. Figures 6(a)-(d) show the relationships between $\mathrm{Xp}_{50}$ and uniaxial compressive strength, Brazilian tensile strength, RIHN, powder factor, respectively. Although it has been already pointed out that the size of fragmented rock depends on the blasting standard and mechanical properties of rock [6], it can be seen from this figure that the data vary widely and no obvious correlation can be recognized. This may be because the crack condition of rock mass, mechanical properties of rocks, blasting standard such as

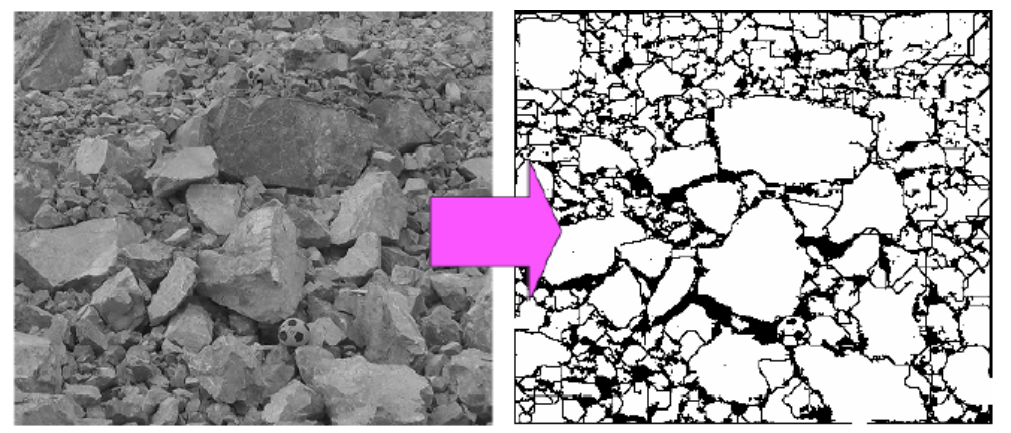

Figure 3. Digitized fragment outlines.

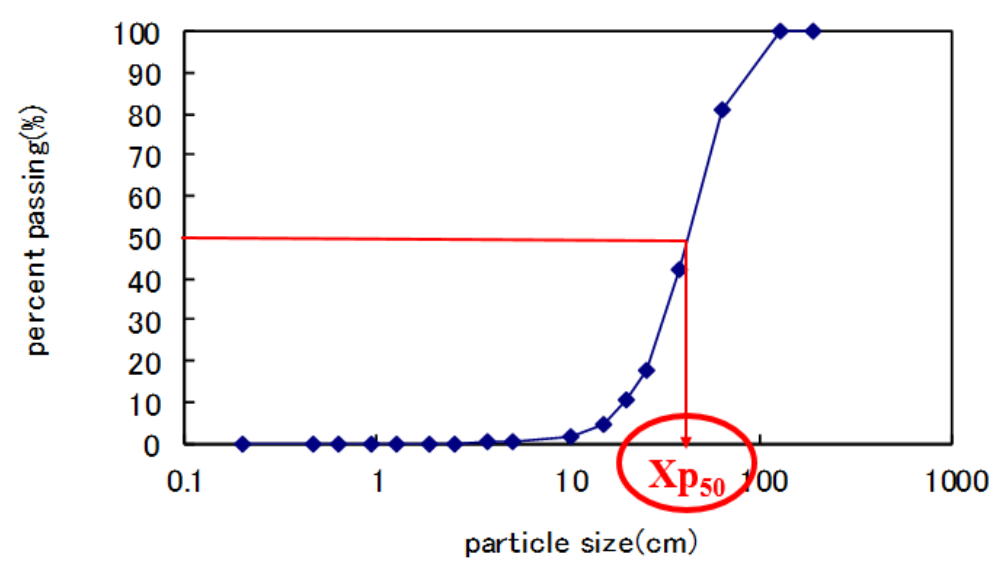

Figure 4. Particle size distribution (Mine B Face 2). 


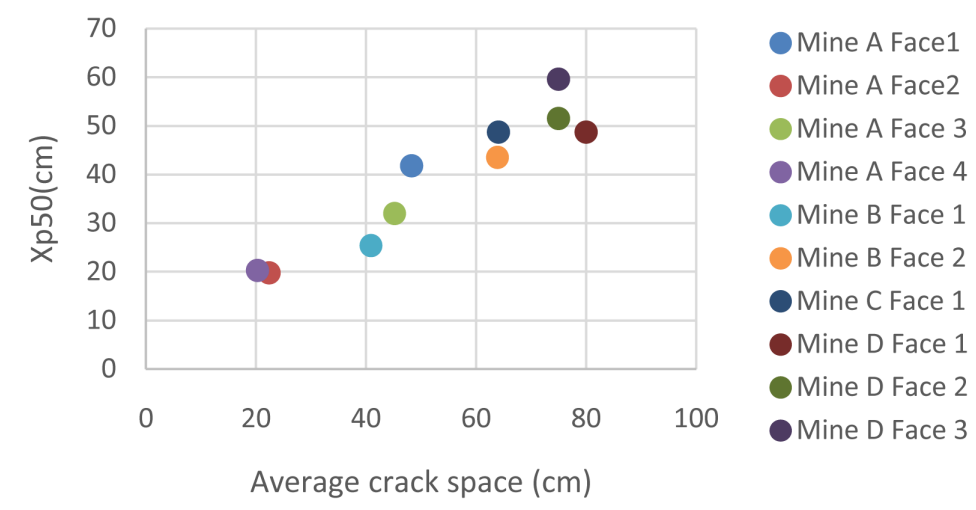

Figure 5. Relationship between representative particle size: $\mathrm{Xp}_{50}$ and average crack space.
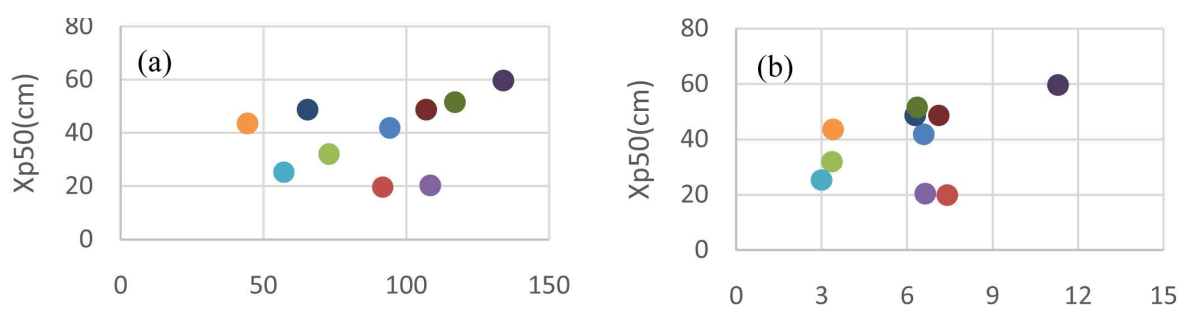

Mine A Face1

- Mine A Face2

- Mine A Face 3

Uniaxial compressive strength (MPa)

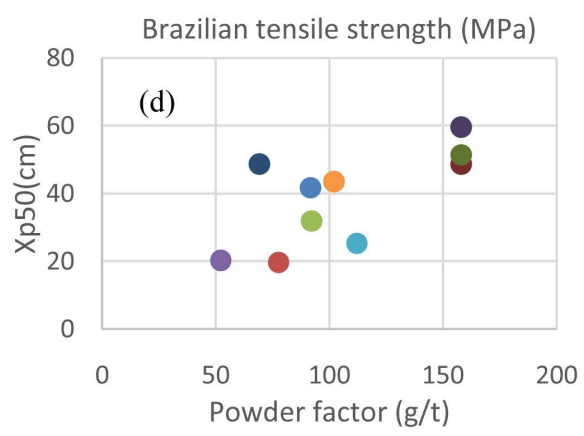

Mine A Face 4

- Mine B Face 1

- Mine B Face 2

- Mine C Face 1

- Mine D Face 1

- Mine D Face 2

- Mine D Face 3

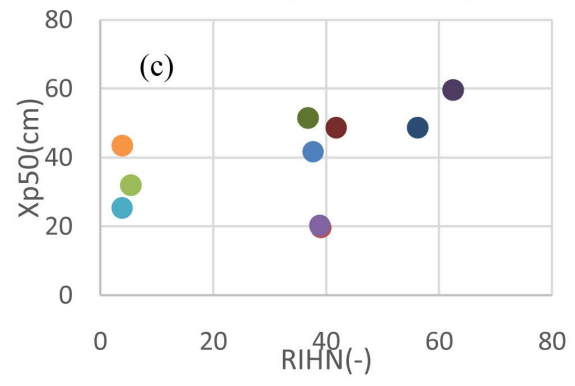

Figure 6. Relationships between representative particle size: $\mathrm{Xp}_{50}$ and (a) uniaxial compressive strength, (b) Brazilian tensile strength, (c) RIHN and (d) powder factor.

Table 3. Representative particle size at $50 \%$ of the gain size accumulation curve: $\mathrm{Xp}_{50}$ at each face.

\begin{tabular}{ccccccccccc}
\hline & Mine A & Mine A & Mine A & Mine A & Mine B & Mine B & Mine C & Mine D & Mine D & Mine D \\
& Face 1 & Face 2 & Face 3 & Face 4 & Face 1 & Face 2 & Face 1 & Face 1 & Face 2 & Face 3 \\
\hline $\mathrm{Xp}_{50}(\mathrm{~cm})$ & 41.8 & 19.8 & 32.0 & 20.3 & 25.4 & 43.5 & 48.7 & 51.5 & 59.6 & 73.5 \\
\hline
\end{tabular}

powder factor are different at different test sites. Here, it is assumed that the crack condition of rock mass has an obvious impact on the size of fragmented rock. It attempts to eliminate this impact from the value of $\mathrm{Xp}_{50}$ as follows. The distance from the mouth of the hole to the first crack is $\mathrm{X}_{1}$, that from the first crack and second one is $X_{2}$, that from the $(n-1)^{\text {th }}$ and $n^{\text {th }}$ ones is $X_{n}$. Here, it is assumed that a rock mass is fragmented according to the existing cracks/fractures, the number of rock particles produced by blasting is $n$ and the shape of them is circular. Besides, it is also assumed that the density of rock mass is constant. In this case, the percent passing is represented as $\left(X_{n} / L\right) \times 100$. Where, $L$ is the length of blast hole. Table 4 shows there presentative particle size at $50 \%$ of the grain size accumulation curve; $\mathrm{Xb}_{50}$ and the value of $\left(\mathrm{Xb}_{50}-\mathrm{Xp}_{50}\right) . \mathrm{Xb}_{50}$ reflects the effect of existing cracks/fractures on the fragmentation size. As it were, the value of $\left(\mathrm{Xb}_{50}-\mathrm{X}_{50}\right)$ should reflect the effect of mechanical properties of rock on fragmentation size. By using the value of $\left(\mathrm{Xb}_{50}-\mathrm{Xp}_{50}\right)$ and considering the 
mechanical properties of rock and powder factor, the data was reanalyzed. Figures 7(a)-(d) show the relationships between the value of $\left(\mathrm{Xb}_{50}-\mathrm{Xp}_{50}\right)$ and uniaxial compressive strength,/Brazilian tensile strength, /RIHN,/ powder factor, respectively. Compared with Figure 6, it can be recognized that the value of $\left(\mathrm{Xb}_{50}-\mathrm{Xp}_{50}\right)$ is correlated strongly with the mechanical properties of rock and powder factor. The weaker the rock is and/or the larger the powder factor is, the larger the value of $\left(\mathrm{Xb}_{50}-\mathrm{Xp}_{50}\right)$ is. Therefore, if the effect of crack condition of rock mass on the size of fragmented rock is eliminated, it can be seen clearly that the mechanical properties of rock and blasting standard also affect the size of fragmented rock.

From the above results, it can be concluded that made clear that the crack conditions of rock mass has an obvious impact on the size of fragmented rock. Moreover, the size of fragmented rock also depends on the mechanical properties of rock and blasting standard. These results fit with empirical knowledge. It can be concluded that the crack conditions of rock mass has to be grasped and evaluated in quantity in order to estimate the size of fragmented rock more accurately.

\section{Design Methodology for Blasting Standard Case Study}

At limestone quarry, it is preferred that the size of fragmented rocks is close to that of final products. Even
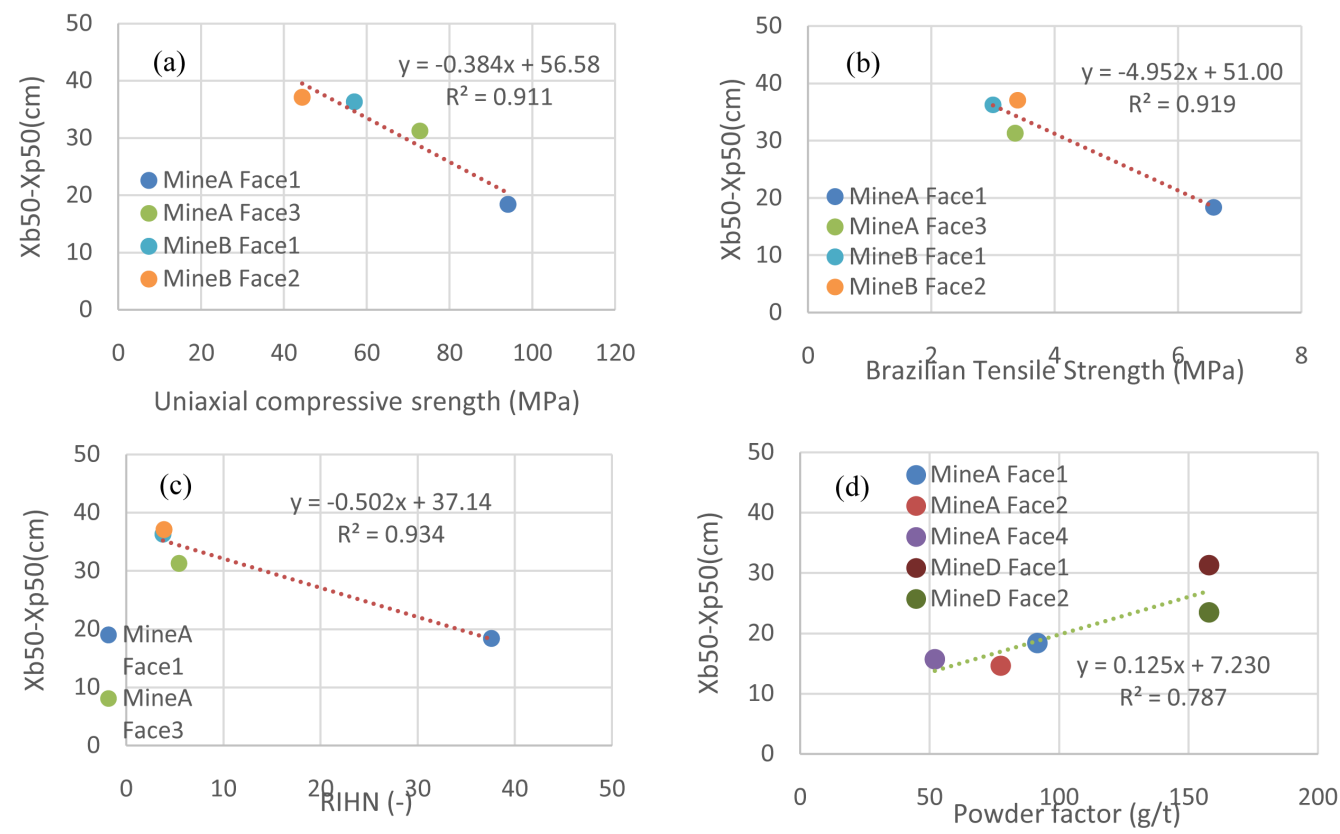

Figure 7. Relationships between representative particle size: $\mathrm{Xp}_{50}$ and (a) uniaxial compressive strength, (b) Brazilian tensile strength; (c) RIHN and (d) powder factor.

Table 4. Xb50 - Xp50, powder factor and mechanical characteristic values of each mine and face.

\begin{tabular}{ccccccccccc}
\hline & Mine A & Mine A & Mine A & MineA & Mine B & Mine B & Mine C & Mine D & Mine D & Mine D \\
& Face 1 & Face 2 & Face 3 & Face 4 & Face 1 & Face 2 & Face 1 & Face 1 & Face 2 & Face 3 \\
\hline $\mathrm{Xb}_{50}(\mathrm{~cm})$ & 60.1 & 34.5 & 63.2 & 36.0 & 61.7 & 137 & 64.1 & 80.0 & 75.0 & 120 \\
$\mathrm{Xb}_{50}-\mathrm{Xp}_{50}(\mathrm{~cm})$ & 18.4 & 14.7 & 31.3 & 15.7 & 36.3 & 37.1 & 15.4 & 31.3 & 23.5 & 46.5 \\
$\begin{array}{c}\text { Uniaxial compressive } \\
\text { strength (MPa) }\end{array}$ & 94.1 & 91.6 & 72.8 & 108.4 & 57.0 & 44.4 & 65.4 & 107 & 117 & 134 \\
$\begin{array}{c}\text { Brazilian tensile } \\
\text { strength (MPa) }\end{array}$ & 6.58 & 7.41 & 3.36 & 6.64 & 3.00 & 3.40 & 6.28 & 7.10 & 6.34 & 11.3 \\
RIHN(-) & 37.6 & 39.0 & 5.4 & 38.8 & 3.8 & 3.9 & 56.2 & 41.7 & 36.8 & 62.5 \\
Powder factor (g/t) & 91.7 & 77.5 & 92.2 & 52.1 & 112 & 102 & 69.2 & 158 & 158 & 158 \\
\hline
\end{tabular}


though the research on control blasting for fragmentation size is conducted by many researchers, the solution has not been developed yet. Appropriate blasting standard and/or measures can still be determined place by place through trial and error. From the results obtained in the above, it can be said that different powder factor have an obvious impact on the size of fragmented rocks. Moreover, it was reported that the size of fragmented rocks can be controlled by changing the length of burden [7]. In order to develop the methodology of designing blasting standard, especially focused on the length of burden, additional field tests were conducted at Mine A. In this field experiment, the burden was changed from $3.7 \mathrm{~m}$ to $4.7 \mathrm{~m}$ which range seems to be not affected on the surrounding environment in terms of the blast-induced ground vibration [8]. The effect of burden on the size of fragmented rocks is discussed as follows.

Figure 8 shows the size distributions of fragmented rocks in different burdens. Here, the curve of "Ideal" is that obtained in Mine A, empirically. From this figure, it can be seen that the larger the burden is the larger the size of fragmented rocks is.

The relationship between the average fragmentation size of rocks and the energy of explosive can be represented as following equation (1) [9].

$$
X=A(K)^{-0.8} Q_{e}^{1 / 6}\left(\frac{115}{E}\right)^{19 / 30}
$$

where, $X$; average size of fragmented rocks, $A$; a factor determined by the hardness of rock, K; powder factor, $Q_{e}$; the amount of explosive per hole, $E$; a parameter for indicating the strength of explosive. As a series of field tests in mine $E$ was conducted at the same face and under the same amount of explosive charge $(40 \mathrm{~kg}$ of ANFO), the value of $Q_{e}$ and $E$ can be considered as a constant. From Equation (1), it can be considered that the average size of fragmented rocks depends only on powder factor and the larger the burden is the larger the size of fragmented rocks is. This result obtained from Equation (1) agrees with that of field tests. Table 5 shows the representative particle size at $80 \%$ of the gain size accumulation curve;

$\mathrm{Xp}_{80}(\mathrm{~cm})$. The reason why the representative particle size at $80 \%$ of the gain size accumulation curve was used in this research is as follows. If less than $80 \%$ of total amount of fragmented rocks can pass the crushing facilities such as crusher and/or grizzly bear, there is an obstacle to operating the preparation plant in Mine A, and its size is about $60 \mathrm{~cm}$. From Figure 4, it can be said that the appropriate burden for obtaining ideal size distribution of fragmented rocks in Mine A is from $4.2 \mathrm{~m}$ to $4.7 \mathrm{~m}$. On the other hand, if the burden is larger than $4.2 \mathrm{~m}$, the more fragmented rocks which size is over $60 \mathrm{~cm}$ are produced and it seems to have an effect on the operation of the preparation plant.

Figure 9 shows the relationship between $\mathrm{Xp}_{80}$ and powder factor. From this figure, Equation (2) can be derived.

$$
\mathrm{Xp}_{80}=490 e^{-(-0.035 t)}
$$

where, $t$; the amount of explosive per volume of rock $\left(\mathrm{kg} / \mathrm{m}^{3}\right)$. From this equation, the appropriate amount of

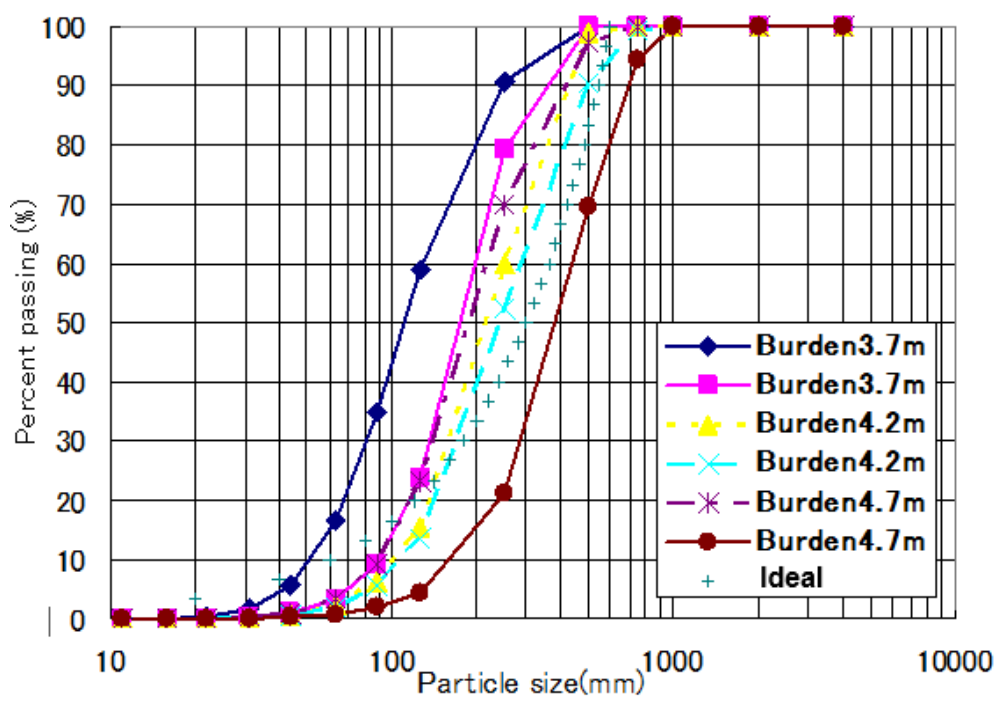

Figure 8. Grain size accumulation curves. 


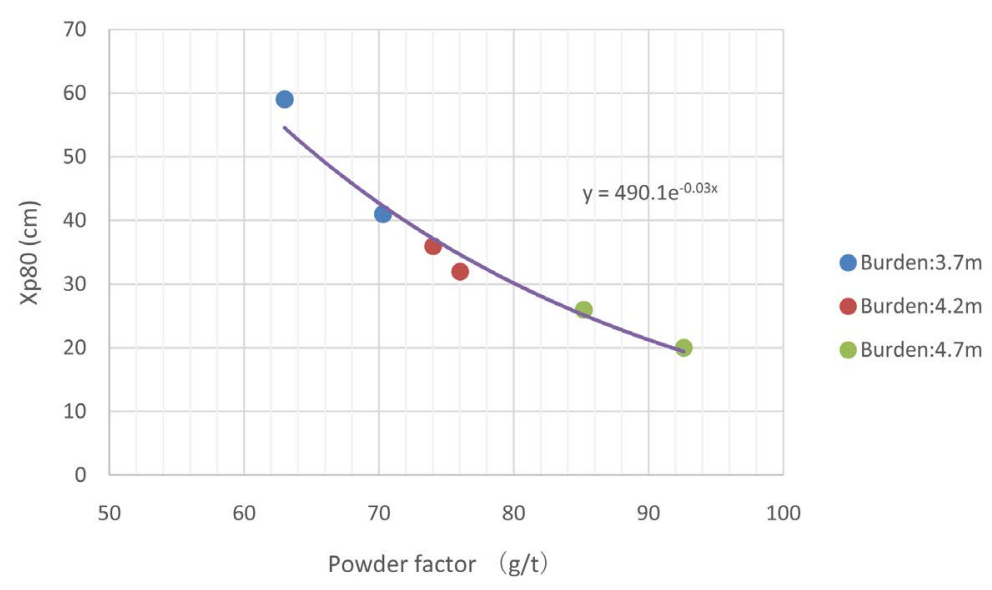

Figure 9. Relationship between $\mathrm{Xp}_{80}$ and powder factor at Mine A.

Table 5. Representative particle size at $80 \%$ of the grain size accumulation curve, $\mathrm{Xp}_{80}$.

\begin{tabular}{cccc}
\hline Burden & $3.7 \mathrm{~m}$ & $4.2 \mathrm{~m}$ & $4.7 \mathrm{~m}$ \\
$\mathrm{Xp}_{80}(\mathrm{~cm})$ & 20,26 & 32,36 & 40,59 \\
\hline
\end{tabular}

explosive can be determined in order to obtain desired size of fragmentation rocks and this equation is helpful to determine the appropriate blasting deign.

\section{Conclusions}

Based on the results of a series of field experiments, the following conclusions can be obtained:

1) In order to predict the size of fragmented rock more accurately, not only basting standard and mechanical properties of rocks, but also crack/fracture condition of rock mass have to be evaluated quantitatively.

2) If the variability of the length of burden is relatively small, as the effect of it on the blast-induced ground vibration is small, the length of burden can be determined based on the desirable size of fragmented rocks in terms of mine operating costs.

In order to verify these trends and develop the guidelines for designing blasting standard, more fields experiments and study have to be conducted.

\section{Acknowledgements}

The authors would like to express our thanks to staffs of Mines A, B, C and D. We also really appreciate cooperation of Dr. Yuji OGATA and Dr. Tei SABURI in Advanced Industrial Science and Technology.

\section{References}

[1] Bhandari, S. (1997) Engineering Rock Blasting Operations. A.A.Balkema, Rotterdam.

[2] Hustrulid, W. (1999) Blasting Principles for Open Pit Mining, Volume 1-General Design Concepts. A.A.Balkema, Rotterdam.

[3] Shimada, H., Matsui, K., Ichinose, M., Sasaoka, T. and Kubota, S. (2006) Study on Effect of Blast Vibration on Size of Fragmentation at Limestone Quarry. Journal of the Mining and Materials Processing Institute of Japan, 122, 11-19. (In Japanese) http://dx.doi.org/10.2473/shigentosozai.122.573

[4] Paley, N.L. (1990) Image Based Fragmentation Assessment. MEngSc Thesis, The University of Queensland (JKMRC), Brisbane.

[5] Sprit Engineering LLC (2003) Manual of Split-Desktop Software. http://www.spliteng.com/download/2102/

[6] Matsui, K. and Shimada, H. (2004) Evaluation of Rock Mass Condition and Effect of Fracture of Rock Mass on Blasting Effect. Sekkaiseki, 330, 57-61. (In Japanese)

[7] Inoue, H., Sasaoka, T., Shimada, H., Hamanaka, A., Matsui, K., Tanaka, H. and Inoue, M. (2014) Study on Control of 
Fragmentation Size by Changing Blasting Pattern at Open Pit Metal Mine. Proceedings of International Symposium on Earth Science and Technology 2014, Fukuoka, 4-5 December 2014, 214-217.

[8] Sasaoka, T., Shimada, H., Hamanaka, A. and Matsui, K. (2011) Study on Blast Vibration and Size of Fragmentation at Limestone Quarry. Proceedings of $20^{\text {th }}$ International Symposium on Mine Planning and Equipment Selection, Almaty, 12-14 October 2011, 714-730.

[9] Persson, P.A., Homberg, R. and Lee, J. (1993) Rock Blasting and Explosives Engineering. CRC Press, Boca Raton. 